J. Perinat. Med. 5 (1977) 84

\section{Fetal and maternal blood glucose, insulin and acid base observations following maternal glucose infusion}

\author{
Axel Feige, Wolfgang Künzel, Hans J. Mitzkat
}

Universitäts-Frauenklinik Würzburg

Arbeitsgruppe Diabetologie im Dept. Innere Medizin der Medizinischen Hochschule

Hannover
In the past conflicting results for the fetal insulin increase following maternal glucose infusion were reported $[2,7,21]$. In conscious rhesus monkeys constant glucose infusion to the mother was followed by maternal and fetal hyperglycemia and as a response to it a 2 to 4 fold increment in fetal insulin occured [22]. Fetal glucose and insulin responses following maternal glucose loads have been repeatedly investigated in fetal cord blood in humans $[16,19,23,28]$. However fetal and maternal glucose levels increase during parturition and are correlated to the base excess [10]. In addition fetal insulin secretion is suppressed in severe acidosis [9], so that cord blood studies are masked by hypoxic episodes which occure during the second stage of labor.

Maternal and fetal glucose and insulin concentration were studied in normal and diabetic pregnancies following a single intravenous injection of glucose to the mother [4]. The fetal insulin response however was of a different kind probably due to the short lasting stimulation of the fetal pancreatic islet cells.

We were therefore interested in the human maternal and fetal glucose and insulin response to a constant glucose infusion to the mother during the first stage of labor sustained for 60 minutes. Elevated fetal glucose concentrations lead in a mild hypoxic fetus to a deterioration of the fetal $\mathrm{pH}$ due to increasing lactate production $[13,24]$. We investi-

\section{Curriculum vitae}

AXEL FEIGE was born in 1941 and obtained his medical degree in 1968. He did clinical and research work from 1970 to 1974 at the Department of $\mathrm{Ob}$ stetrics and Gynecology, Hannover, since 1974 at the Universitäts-Frauenklinik Würzburg. Chief areas of interest: Carbohydrate metabolism in pregnancy, pregnancy and diabetes mellitus, ultrasonics in obstetrics.

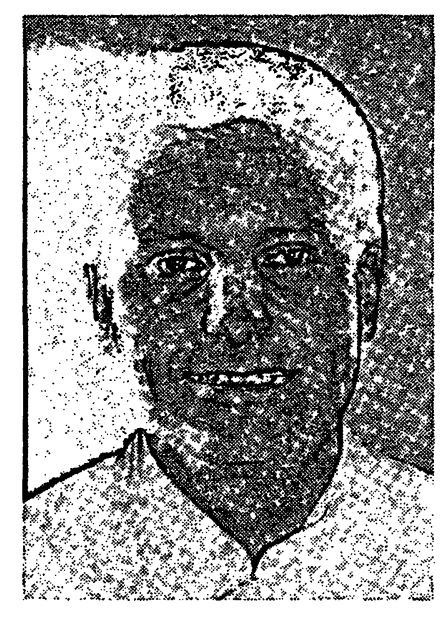

gated therefore in addition the fetal acid base parameters.

The present experiments demonstrate a close relationship between the maternal and fetal glucose concentration. The fetal insulin increased by about $86 \%$ after 60 min glucose infusion to the mother A deterioration of the fetal $\mathrm{pH}$ and base excess could not be established even at high glucose concentrations.

\section{Methods}

\subsection{Patient material}

The study comprises 11 primigravid patients (age $17-28$ years) with a gestational age of $38-40$ 
weeks. The course of pregnancy had been without any complications. The birthweight of the babies was $3330 \mathrm{~g}$ (SD 480). Neither the family history nor the case history revealed any signs of disturbances in carbohydrate metabolism.

\subsection{Experimental procedure}

The studies were performed during the first stage of labor. To achieve a constant level of glucose in the maternal blood a single intravenous bolus injection of $330 \mathrm{mg} / \mathrm{kg}$ glucose was given and followed by a glucose infusion of $27.5 \mathrm{mg} / \mathrm{kg} / \mathrm{min}$ for $60 \mathrm{~min}$. From the hyperemized maternal earlobe and fetal scalp blood samples for glucose determination and the acid base parameters were

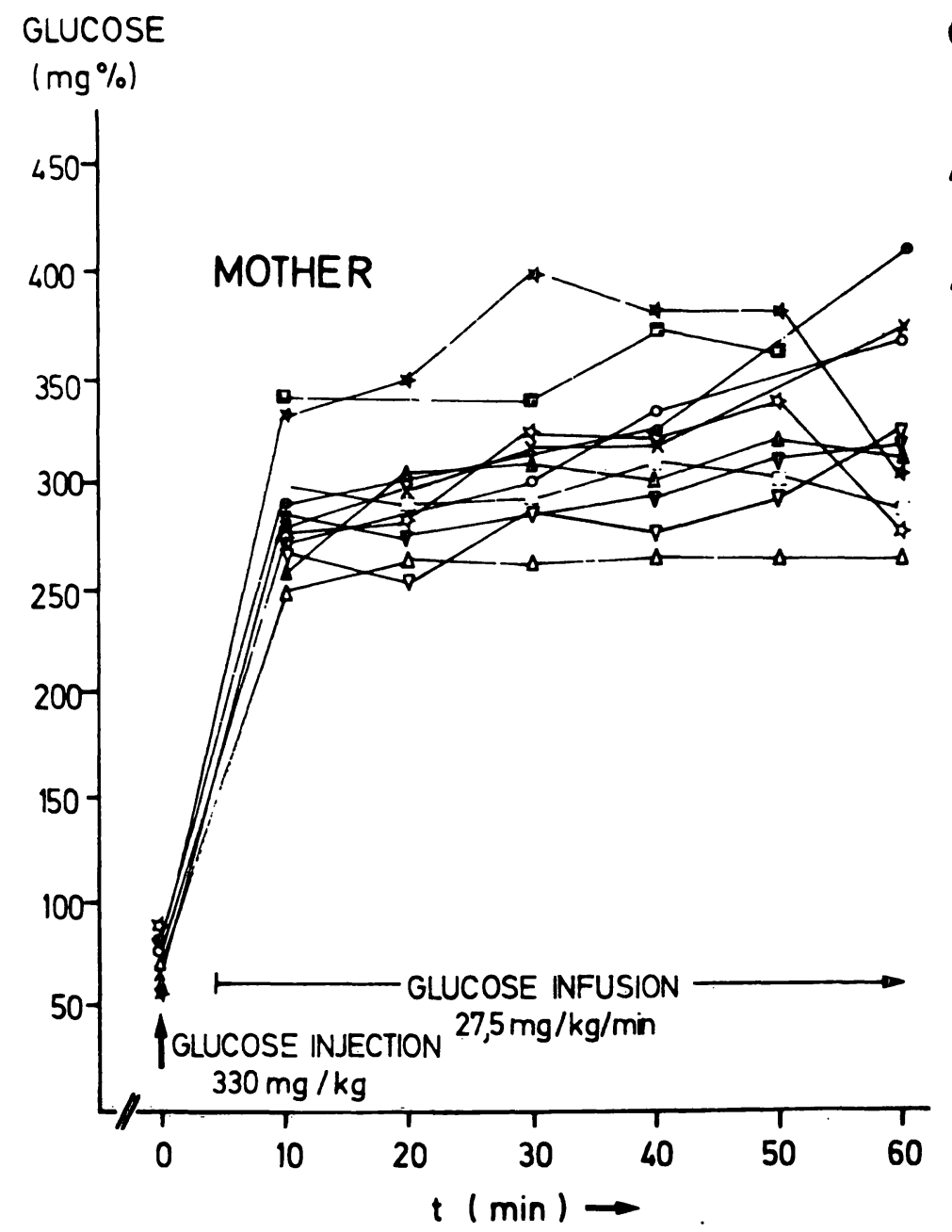

collected at intervals of $10 \mathrm{~min}$. This was not possible in each case as the figures show. Insulin was estimated in the maternal vein blood and the blood of the fetal scalp drawn at the same intervals.

Glucose concentration (GC) was measured by an enzymatic method [5]. Immuno-reactive insulin (IRI) was determined by a modification of the radioimmunological method [12]. The base excess (BE) and the $\mathrm{pH}$ were measured with commercial equipment (Radiometer Copenhagen).

\section{Results}

\subsection{Maternal and fetal glucose}

In Fig. 1 the glucose concentration of the maternal and fetal blood of each experiment is shown.

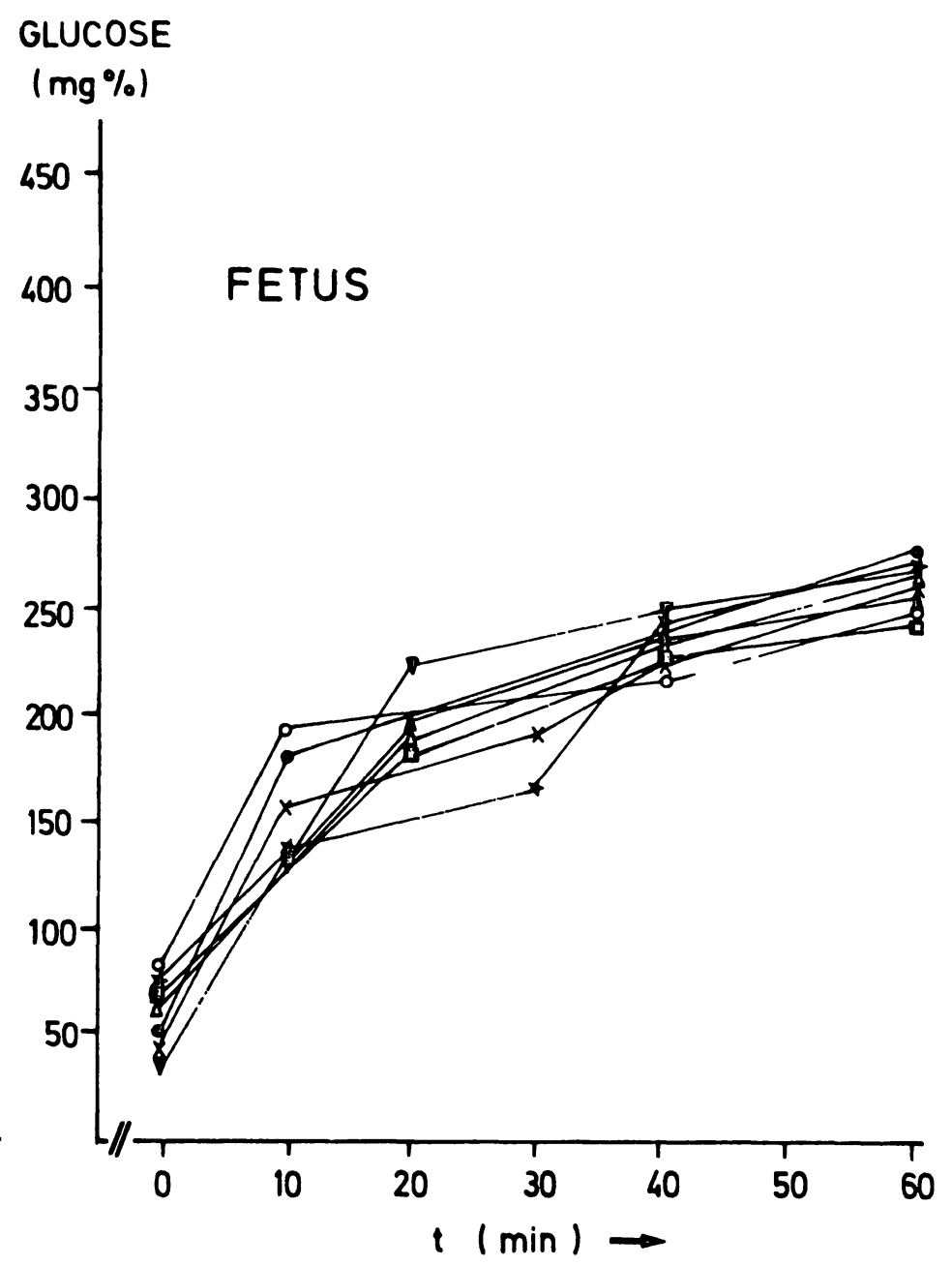

Fig. 1. Maternal and fetal blood glucose after a bolus injection of glucose followed by a 60 min. glucose infusion to the mother. After the injection of $330 \mathrm{mg} / \mathrm{kg}$ bodyweight glucose a rapid increase of maternal blood glucose occured within $10 \mathrm{~min}$ : $275.7 \mathrm{mg} \%$ (SD 21.3). This glucose level was maintained by a continuous glucose infusion of $27.5 \mathrm{mg} / \mathrm{kg} / \mathrm{min}$. The maternal blood glucose was after $60 \mathrm{~min}$. infusion $326.5 \mathrm{mg} \%$ (SD 46.9). Fetal glucose increased continuously until the end of the glucose infusion (at control $176.5 \mathrm{mg} \%$ (SD 20.4) after $60 \mathrm{~min} .249 .2 \mathrm{mg} \%$ (SD 24.0). The asterisks (*) indicate the values of a prediabetic mother. 
Following the injection of $330 \mathrm{mg} / \mathrm{kg}$ glucose intravenously the maternal blood glucose increased within $10 \mathrm{~min}$ from $85.9 \mathrm{mg} / 100 \mathrm{ml}$ (SD 7.9) to $280 \mathrm{mg} / 100 \mathrm{ml}$ (SD 25.9). This level was maintained roughly by a continuous glucose infusion of $27.5 \mathrm{mg} / \mathrm{kg} / \mathrm{min}$. The maternal glucose concentration after $60 \mathrm{~min}$ infusion was $327.5 \mathrm{mg} / 100 \mathrm{ml}$ (SD 43.6).

Before the injection of glucose to the mother the fetal blood glucose was $64.1 \mathrm{mg} / 100 \mathrm{ml}$ (SD 7.6). As a result of the glucose infusion the glucose concentration in the fetal scalp blood increased to $191.0 \mathrm{mg} / 100 \mathrm{ml}$ (SD 24.8) after $10 \mathrm{~min}$ and to
$247.5 \mathrm{mg} / 100 \mathrm{ml}$ (SD 25.0) after $60 \mathrm{~min}$ infusion, respectively.

In Fig. 2 the glucose concentration of the fetal scalp blood is plotted to the blood glucose in the maternal capillary blood. The calculated regression line deviates from the line of identity with increasing maternal blood glucose. The different symbols in high maternal glucose concentrations indicate the time of sampling. Compared with the line of identity the difference between the maternal and the fetal blood glucose during the control period was about $22 \mathrm{mg} / 100 \mathrm{ml}$ and rose to $80 \mathrm{mg} / 100 \mathrm{ml}$ at the end of the infusion.

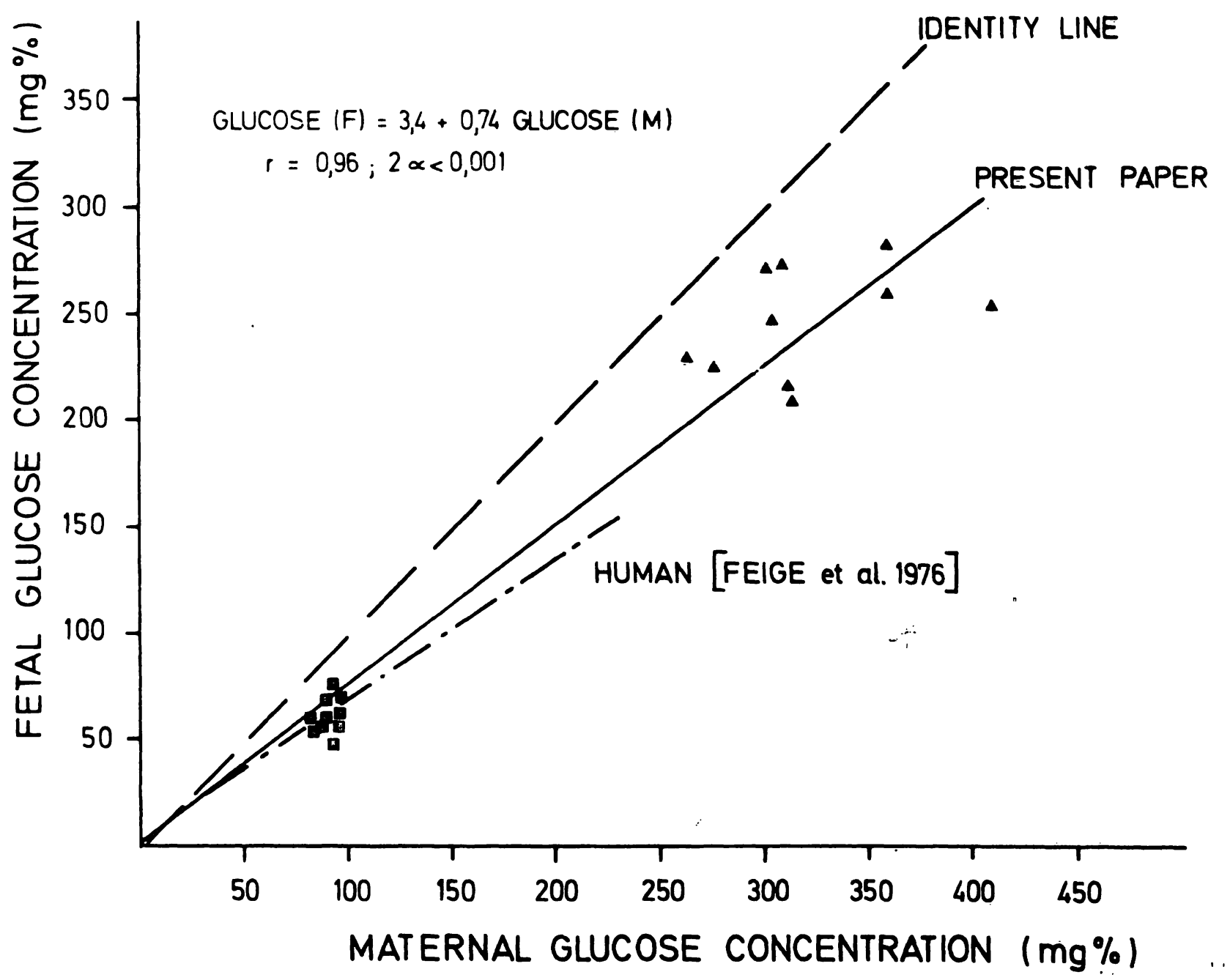

Fig. 2. The relationship between fetal and maternal blood glucose. The solid line shows the regression line of the fetal and maternal blood glucose at control ( $( \pm)$ and after 60 min. (A) glucose infusion to the mother. The maternal-fetal glucose difference rises with increasing maternal glucose concentration.

The dotted line shows the fetal-maternal relationship of blood glucose in human under hypoxic conditions.

This regression line is identical with the present observations, revealing a fairly rapid glucose transfer across the hemochorial placenta. 
The present results and the regression line are in agrecment with our previous observations [10] which had been achieved under quite different conditions (see discussion) and deviate from the results obtained in sheep $[17,18,26]$.

\subsection{Matemal and fetal insulin}

In Fig. 3 the insulin response to the increased maternal and fetal blood glucose of each experiment is demonstrated. The increase of the glucose concentration in the maternal blood was not paralleled by the same rise of insulin in each case. The maternal insulin concentration at control was $24.0 \mu \mathrm{U} / \mathrm{ml}$. In one case (asterisks) the insulin secretion rose after $10 \mathrm{~min}$ up to $232 \mu \mathrm{U} / \mathrm{ml}$ followed by a rapid decrease to about $60 \mu \mathrm{U} / \mathrm{ml}$. In the fetal blood there was only a slight response of insulin secretion to the elevated glucose level. The IRI-concentration at control was $17.0 \mu \mathrm{U} / \mathrm{ml}$ (SD 5.2). After 40 and $60 \mathrm{~min}$ of glucose infusion to the mother the IRI-concentration was $163 \%$ and $180 \%$ of its control, respectively. In the case of an abnormal maternal insulin secretion the fetal insulin however showed a continuous increase
IRI

$(w U / m l)$

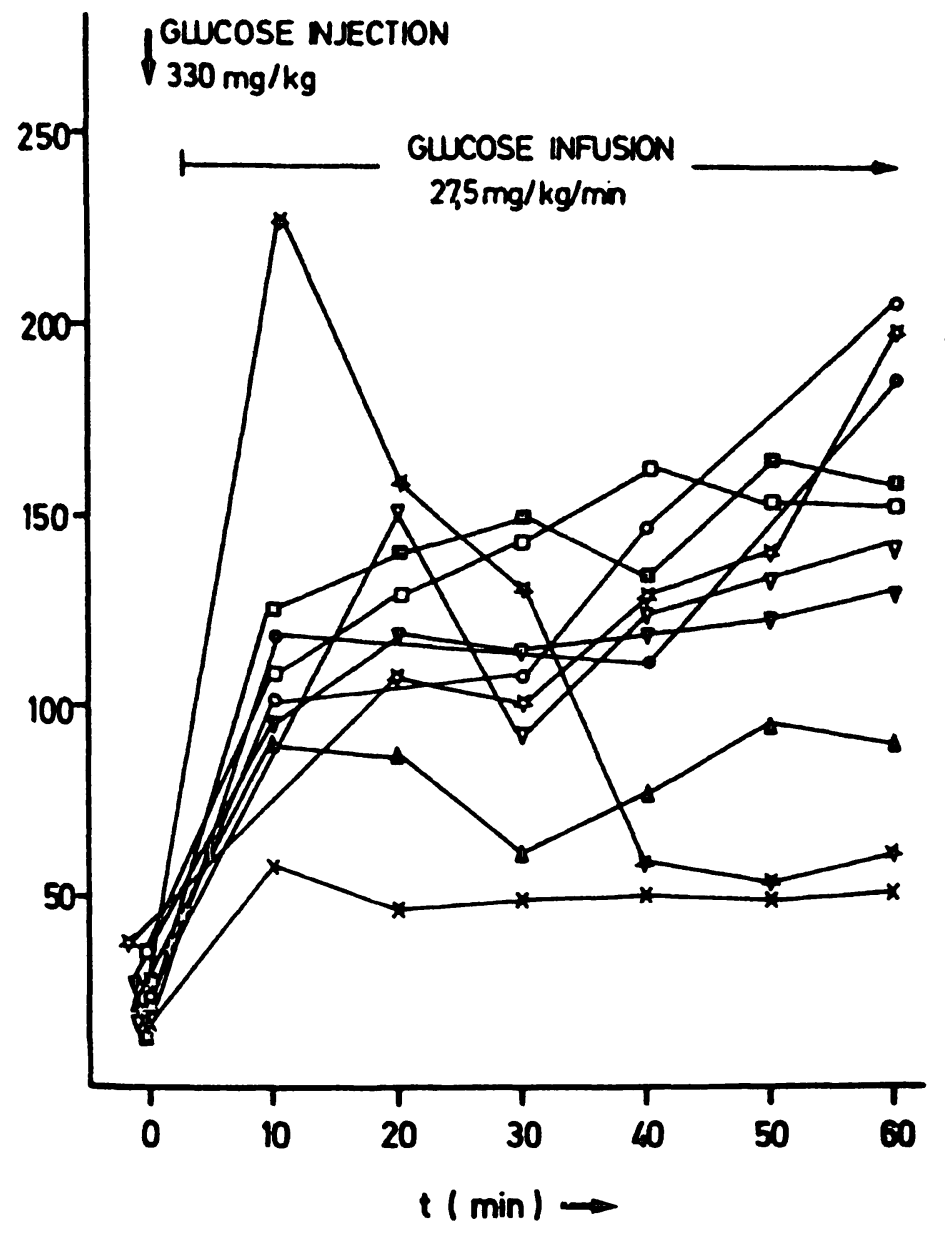

IRI

$(w U / m)$

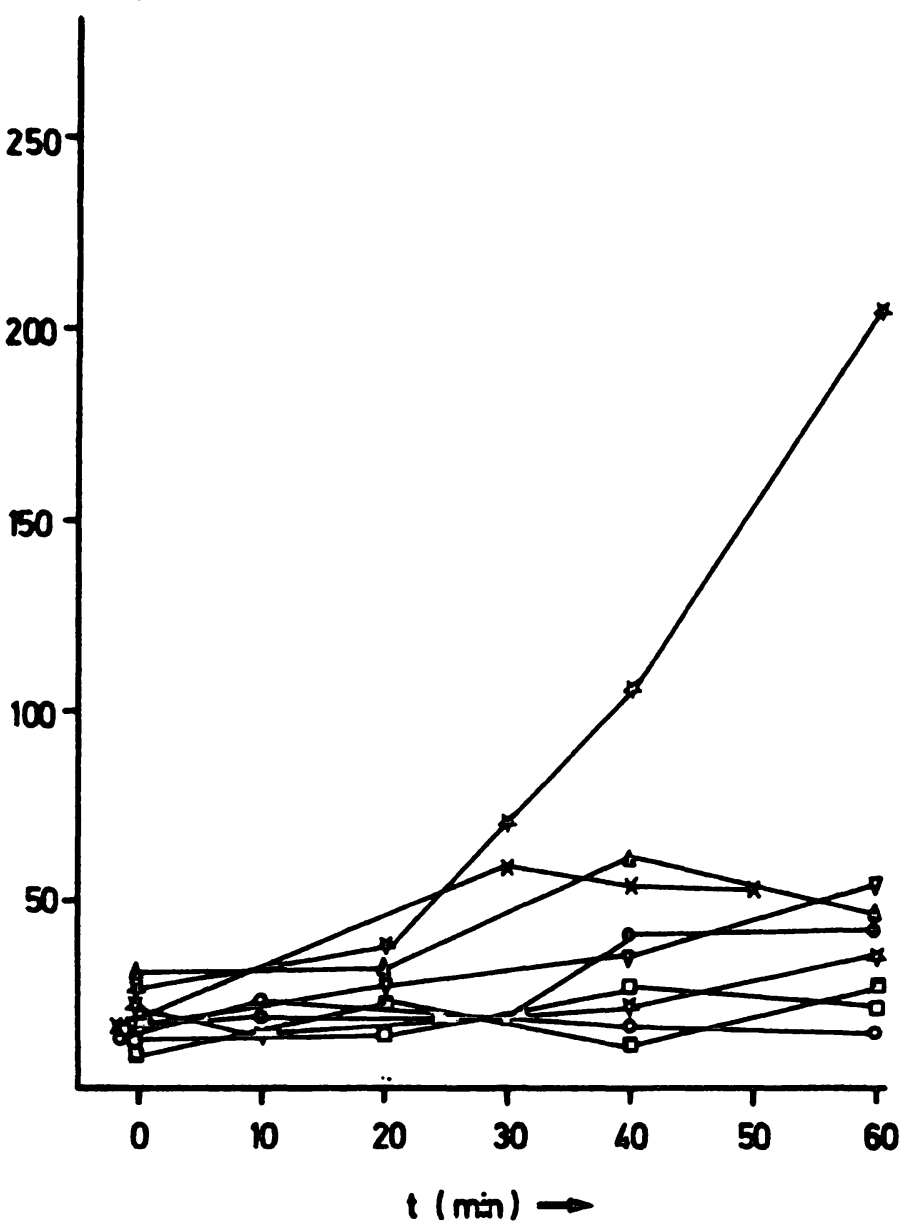

Fig. 3. Maternal and fetal insulin (IRI) concentration after a bolus injection of glucose followed by a 60 min. glucose infusion to the mother. The increase of maternal blood glucose is accompanied with an increase of maternal insulin (IRI). The IRI-concentration was at control $24.0 \mu \mathrm{U} / \mathrm{ml}$ (SD 8.0) and rose continuously up to $98.7 \mu \mathrm{U} / \mathrm{ml}$ (SD 22.8), (10 $\mathrm{min}$.) and $152.3 \mu \mathrm{U} / \mathrm{ml}$ (SD 51.5) after $60 \mathrm{~min}$. glucose infusion. The values of the prediabetic mother (asterisks) are excluded by calculating the mean. Fetal insulin concentration did not change significantly during the initial time course (at control $17.0 \mu \mathrm{U} / \mathrm{ml}$ ) (SD 5.2). After $30 \mathrm{~min}$. however, a small increase up to $33.0 \mu \mathrm{U} / \mathrm{ml}$ (SD 26.4) and $30.1 \mu \mathrm{U} / \mathrm{ml}$ (SD 14,1) (60 $\mathrm{min}$.$) , respectively took place. The fetus of the prediabetic mother \left(^{*}\right)$ showed a tremendous rise in insulin. These values were not used in calculating the mean. 
(asteriks) from $26.0 \mu \mathrm{U} / \mathrm{ml}$ at control to $216 \mu \mathrm{U} / \mathrm{ml}$ at the end of infusion.

\subsection{Fetal weight and insulin response}

In Fig. 4 the insulin secretion as a response to the rise of the fetal blood glucose after $60 \mathrm{~min}$ is related to the fetal birth weight. The increase of the insulin secretion following the glucose stimulation may be assumed to indicate the reactivity of the pancreatic islet cells. The calculated quotient is low in normal fetal birth weight, i.e. the insulin secretion related to the glucose increase is less if the fetal weight is in a normal range. However there is a steep increment of the quotient in cases of high birth weight, i.e. the fetal insulin secretion by approximately the same rise of glucose is much more pronounced in babies with higher birthweights.

\section{$2.4 \mathrm{pH}$ and base excess of the maternal and fetal blood}

In Tab. I the $\mathrm{pH}$ and base excess of the maternal and fetal blood are listed. The $\mathrm{pH}$ and base excess in the fetal blood by the first analyses was 7.37 (SD 0.05) and - $3.8 \mathrm{meq} / \mathrm{l}$ (SD 2.0), respectively. The maternal $\mathrm{pH}$ was 7.45 (SD 0.05) and the base excess $-3.5 \mathrm{meq} / 1$ (SD 2.1). Neither in the fetal blood nor in the maternal blood were significant

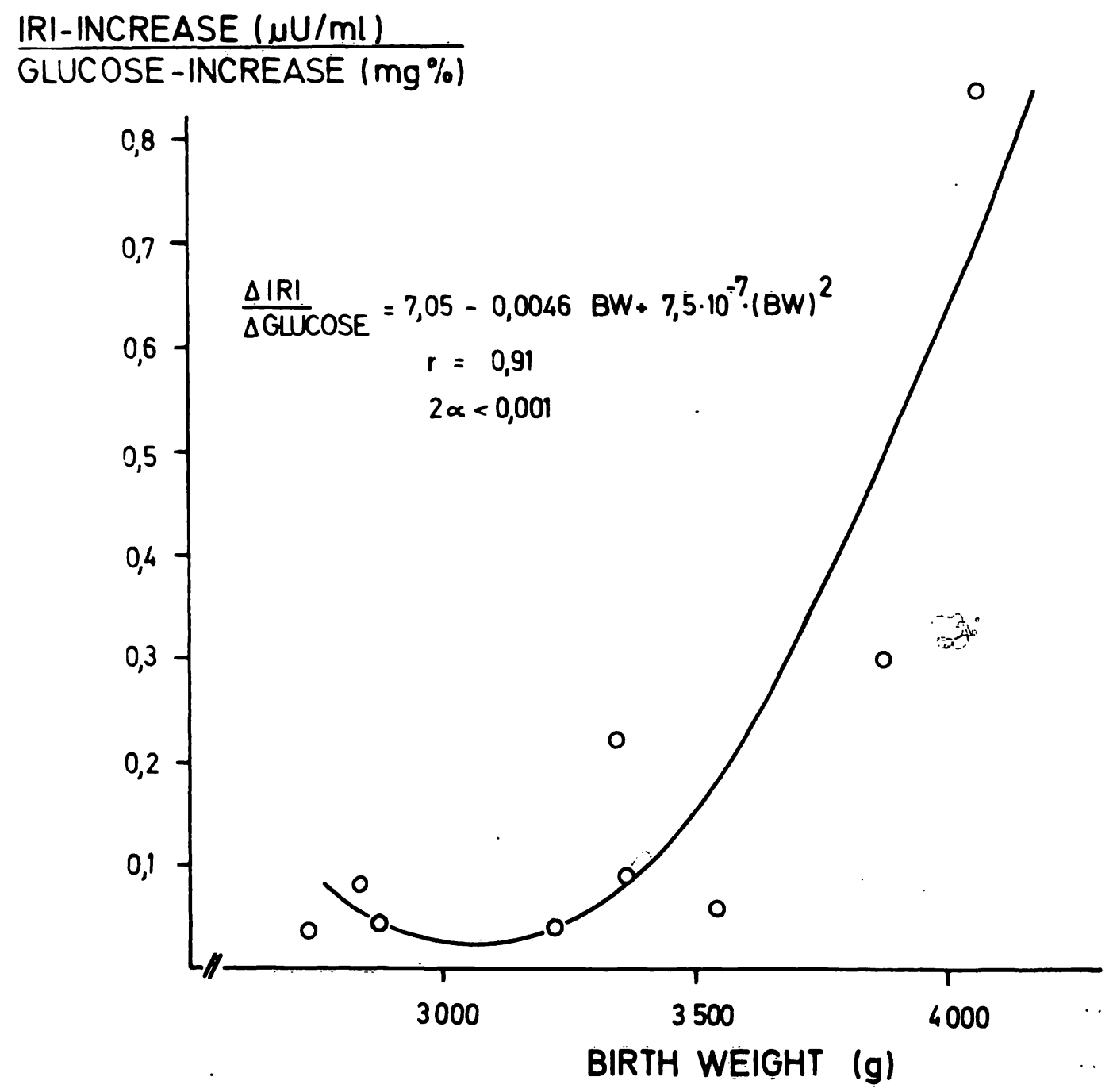

Fig. 4. The relationship between fetal insulin secretion and fetal birth weight after 60 min. glucose infusion to the mother. A polynomial regression line was adapted to the respective data. Birthweight over $3500 \mathrm{~g}$ is associated with an elevated insulin secretion by an equal rise of glucose. This fact demonstrates a hyperinsulinism probably due to pancreatic islet cell hypertrophy generated by the chronic fetal glucose load. 
Tab. I. Acid base observation in the maternal capillary and fetal scalp blood during the first stage of labor before and after $60 \mathrm{~min}$. glucose infusion to the mother. There is no difference in $\mathrm{pH}$ and base excess in the maternal and fetal blood before and after glucose-infusion. $(\bar{x}=$ mean, $S D=$ standard deviation, $N=$ number of cases $)$

\begin{tabular}{|c|c|c|c|c|}
\hline & & & $\begin{array}{l}\text { Before } \\
\text { glucose infusion } \\
\text { to the mother }\end{array}$ & $\begin{array}{l}\text { After } 60 \text { minutes } \\
\text { glucose infusion } \\
\text { to the mother }\end{array}$ \\
\hline \multirow[t]{2}{*}{ Fetal scalp blood } & $\mathrm{pH}$ & $\begin{array}{l}\bar{x} \\
S D \\
N\end{array}$ & $\begin{array}{l}7,37 \\
0,05 \\
10\end{array}$ & $\begin{array}{l}7,35 \\
0,04 \\
8\end{array}$ \\
\hline & Base Excess (meq/l) & $\begin{array}{l}\bar{x} \\
S D \\
N\end{array}$ & $\begin{array}{c}-3,8 \\
2,0 \\
10\end{array}$ & $\begin{array}{c}-3,8 \\
1,4 \\
8\end{array}$ \\
\hline \multirow[t]{2}{*}{$\begin{array}{l}\text { Maternal capillary } \\
\text { blood }\end{array}$} & $\mathrm{pH}$ & $\begin{array}{l}\bar{X} \\
S D \\
N\end{array}$ & $\begin{array}{l}7,45 \\
0,05 \\
9\end{array}$ & $\begin{array}{l}7,46 \\
0,05 \\
8\end{array}$ \\
\hline & Base Excess (meq/1) & $\begin{array}{l}\bar{X} \\
S D \\
N\end{array}$ & $\begin{array}{c}-3,5 \\
2,1 \\
8\end{array}$ & $\begin{array}{c}-3,7 \\
1,7 \\
7\end{array}$ \\
\hline
\end{tabular}

changes of the above mentioned parameters noted. A relationship between the glucose concentration and the base excess could not be proved.

\section{Discussion}

The present investigations were designed to study the effect of a maternal glucose load on fetal blood glucose and its stimulatory effect on the fetal insulin secretion as well as its effect on the acid base status of the fetus during the first stage of labor. This time was chosen because alterations in fetal blood glucose and base excess take place during the second stage of labor and might alter fetal insulin secretion $[9,10]$.

3.1 The effect of glucose infusion to the mother on maternal and fetal blood glucose and insulin

Glucose: The bolus injection of $330 \mathrm{mg} / \mathrm{kg}$ glucose to the mother and the continuation of the glucose load by infusion of $27.5 \mathrm{mg} / \mathrm{kg} / \mathrm{min}$ to the mother raised the maternal glucose level from $85.9 \mathrm{mg} /$ $100 \mathrm{ml}$ to $280 \mathrm{mg} / 100 \mathrm{ml}$ after $10 \mathrm{~min}$. This concentration was fairly well maintained during a period of $60 \mathrm{~min}$. The rapid increase in maternal blood glucose was not in parallel with the glucose elevation in the fetal blood. After $10 \mathrm{~min}$ it was
$176 \mathrm{mg} / 100 \mathrm{ml}$ and reached its highest level after $60 \mathrm{~min}$ infusion: $247.5 \mathrm{mg} / 100 \mathrm{ml}$. The slow rise of the fetal blood glucose may be a result of the placental barrier to glucose.

The maternal glucose difference increased significantly during maternal hyperglycemia (Fig. 2). This is in accordance with earlier observations $[3,6,7,10,17,20,21]$. There is no difference between the present and the previous findings under hypoxic conditions [10]. This may account for the fairly rapid glucose transfer across the placenta.

Factors which might be responsible for the increased maternal-fetal glucose difference are a saturation of the transport mechanism for glucose $[8,14,31]$ and an increased glucose consumption by the placenta. Recently published observations in sheep by Battaglia and Meschia [3] and Simmons èt al. [27] however indicate, that for the increment in maternal-fetal glucose difference the rise in fetal glucose uptake may be the most important factor. This is supported by the increase of fetal insulin and thus glucose utilization.

Insulin: The maternal and fetal glucose load was paralleled by an increase of maternal and fetal insulin. The level for maternal insulin prior to infusion was $24.0 \mu \mathrm{U} / \mathrm{ml}$. The maternal insulin increase was scattered over a wide range. The 
maternal insulin response in this series is compatible with previous observations by FEIGE and MITZKAT [11] and the studies by OAKLEY [20] and GARDMARK [13]. The baseline fetal insulin concentration was $17.0 \mu \mathrm{U} / \mathrm{ml}$ and increased only by $86 \%$. This small increase in fetal insulin is not consistent with the findings in rhesus monkeys [22], and in sheep [2]. In fetal rhesus monkeys a two to four fold increment in fetal insulin $(50-240 \mu \mathrm{U} / \mathrm{ml})$ is associated with a fetal hyperglycemia of 225$325 \mathrm{mg} \%$. In sheep an even higher insulin release was observed with fetal glucose concentrations of $100-160 \mathrm{mg} / 100 \mathrm{ml}$. The low fetal pancreatic islet cell response in the present studies may be explained by in-vitro studies concerning the insulin release of fetal pancreas slices during incubation in media with different glucose concentration [1]. The maximum insulin release was observed in a medium containing $80-150 \mathrm{mg} / 100 \mathrm{ml}$ glucose. In higher glucose concentrations $(300 \mathrm{mg} / 100 \mathrm{ml})$ the release was equal with the release at zero concentrations.

However, in one case of an accidentally studied mother with initial hyperinsulinism we observed a tremendous fetal insulin secretion following glucose load rising from $26.0 \mu \mathrm{U} / \mathrm{ml}$ to $216 \mu \mathrm{U} / \mathrm{ml}$. This case implies that a chronic fetal glucose load which occurs in mothers, with a poor insulin response to glucose, results in a hypertrophy of the fetal pancreatic islet cells. A very interesting observation in this context was the correlation of the fetal weight to the rise of insulin per glucose elevation observed after $60 \mathrm{~min}$ glucose infusion (Fig. 4). Therefore maternal hyperglycemia as seen in prediabetic and diabetic patients with poor control of maternal blood sugar can be considered as the initial step for fetal overweight and complications

\section{Summary}

The aim of the present investigation was to examine the fetal and maternal blood glucose and insulin response following glucose infusion to the mother.

The studies were performed on 11 primigravid patients with a gestational age of $38-40$ weeks during the first stage of labor. Glucose was given intravenously by a bolus injection of $330 \mathrm{mg} / \mathrm{kg}$ body weight, followed by a glucose infusion of $27.5 \mathrm{mg} / \mathrm{kg} / \mathrm{min}$ for $60 \mathrm{~min}$. Glucose concentration, immuno-reactive insulin (IRI), pH and base excess of the maternal and fetal blood were measured before and during maternal glucose load. Maternal blood such as placental hypertrophy and fall in diffusing capacity [30].

\subsection{The effect of maternal glucose load on the fetal acid-base-status}

The increase in fetal blood glucose in humans [13], and in sheep $[2,25]$ is associated with an increase in plasma lactate. In sheep there exists a good correlation between plasma lactate and glucose which is still lacking for the human fetus. The rise of plasma lactate should correlate with the fall of the fetal buffer base, i.e. the base excess of the fetus. With the present investigations no change in the fetal $\mathrm{pH}$ and base excess could be demonstrated. The base excess was $-3.8 \mathrm{meq} / 1$ before and - $3.8 \mathrm{meq} / 160 \mathrm{~min}$. after glucose infusion to the mother. This is consistent with the findings of GARDMARK et al. [11] describing however an increase of maternal-fetal $\mathrm{pH}$ difference to 0.17 units.

Two factors may be responsible for the different findings in sheep and human. As pointed out by SHELLEY et al. [25] hyperglycemia of the fetus might be fatal only if it coincides with hypoxic episodes. Hypoxic episodes however can be neglected in the present studies because no fetal heart rate decelerations could be seen during the time of observation.

In addition it is known that lactic acid does not cross the syndesmo-chorial placenta of the sheep [29] however is transferred in exchange to bicarbonate in both directions of the human hemochorial placenta [15]. Taking this in tótconsideration it may be assumed that at physiological flow rates on both sides of the placenta an accumulation of plasma lactate in the human fetus will not occur, while it takes place in the sheep fetus.

glucose rose within $10 \mathrm{~min}$. up to $280.0 \mathrm{mg} \%$ (SD 25.9). This level could be fairly maintained throughout the experiment. The maternal glucose was after $60 \mathrm{~min}$. infusion $326.5 \mathrm{mg} \%$ (SD 46.9). Fetal glucose concentration rose continuously from $65.8 \mathrm{mg} \%$ (SD 5.8) at control to $249.2 \mathrm{mg} \%$ (SD 23.3) after $60 \mathrm{~min}$.

The increase of maternal and fetal glucose was associated with an elevation of immuno-reactive insulin (IRI). The maternal insulin was $24.0 \mu \mathrm{U} / \mathrm{ml}$ (SD 8.0). It was scattered over a wide range $(55.4 \mu \mathrm{U} / \mathrm{ml}-217.1 \mu \mathrm{U} / \mathrm{ml})$ after $60 \mathrm{~min}$. glucose infusion. The fetal insulin was $17.0 \mu \mathrm{U} / \mathrm{ml}$ (SD 5.2) 
at control and rose by $86.5 \%$ (SD 80.5 ) after $60 \mathrm{~min}$. glucose load.

One case of a mother with a subclinical diabetes mellitus deviated where the fetal insulin rose from $26.0 \mu \mathrm{U} / \mathrm{ml}$ at control to $215.6 \mu \mathrm{U} / \mathrm{ml}$ after $60 \mathrm{~min}$. infusion.

The increase of insulin per glucose rise was correlated to fetal body weight. During glucose infusion to the mother of both, fetal and maternal, acid base parameters remained unchanged.
From these observations it may be concluded that in the human fetus insulin secretion following a single glucose load is generally low, however, it increases in cases where the maternal insulin response to glucose load is abnormal. This might be related to a chronic stimulation by glucose of the fetal pancreatic islet cells in poorly controlled diabetic and possibly prediabetic patients.

Keywords: Acid-base-balance, blood glucose, fetus, glucose infusion, insulin, mother.

\section{Zusammenfassung}

Glukosekonzentration, Insulinsekretion und Säure-BasenStatus im fetalen und mütterlichen Blut nach GlukoseInfusion an die Mutter

Das Ziel der vorliegenden Arbeit war die Glukosekonzentration im mütterlichen und fetalen Blut und die Insulinsekretion nach Glukoseinfusion an die Mutter zu untersuchen.

Die Untersuchungen wurden an 11 Primiparae in der 38. -40. Schwangerschaftswoche während der Eröffnungsperiode durchgeführt. Nach einer Bolusinjektion von $330 \mathrm{mg}$ Glukose pro Kilogramm Körpergewicht wurde zur Aufrechterhaltung eines konstanten Glukosespiegels bei der Mutter $27.5 \mathrm{mg} / \mathrm{kg}$ Körpergewicht/min Glukose über $60 \mathrm{~min}$ infundiert. Bei Mutter und Fet wurden vor und während der Infusion die Glukosekonzentration, das immuno-reaktive Insulin, $\mathrm{pH}$ und Base-Excess bestimmt. Die materne Glukosekonzentration stieg innerhalb von $10 \mathrm{~min}$ auf $280.0 \mathrm{mg} / 100 \mathrm{ml}$ (SD 25.9) an und betrug nach $60 \mathrm{~min}$ Infusionsdauer $326.5 \mathrm{mg} / 100 \mathrm{ml}$ (SD 46.9). Die fetale Glukosekonzentration stieg kontinuierlich von $65.8 \mathrm{mg} / 100 \mathrm{ml}$ (SD 5.8) zu Beginn der Infusion auf $249.2 \mathrm{mg} / 100 \mathrm{ml}$ (SD 24.0) nach $60 \mathrm{~min}$ dauernder Infusion an.

Gleichzeitig mit dem Anstieg der fetalen und maternen Glukosekonzentration stieg das immuno-reaktive Insulin
(IRI) an. Zu Beginn der Infusion betrug das materne IRI $24.0 \mu \mathrm{E} / \mathrm{ml}$ (SD 8.0), nach $60 \mathrm{~min}$ Infusionszeit betrug das IRI $152.3 \mu \mathrm{E} / \mathrm{ml}$ (SD 51.5). Die fetale Insulinkonzentration betrug zu Beginn der Infusion $17.0 \mu \mathrm{E} / \mathrm{ml}$ (SD 5.2) und war nach $60 \mathrm{~min}$ dauernder Glukoscinfusion an die Mutter um 86,5\% (SD 80,5) erhöht. Deutlich anders verhielt sich die Insulinsekretion des Feten einer Mutter mit latentem Diabetes mellitus. Das immuno-reaktive Insulin betrug vor der Infusion $26.0 \mu \mathrm{E} / \mathrm{ml}$ und stieg nach 60 Minuten dauernder Infusion auf $215,6 \mu \mathrm{E} / \mathrm{ml}$ an.

Der Anstieg der fetalen Insulinkonzentration pro Anstieg der fetalen Glukosekonzentration war nach 60 Minuten dauernder Infusion mit dem Geburtsgewicht korreliert.

Während der Glukoseinfusion an die Mutter waren die Parameter des Säure-Basen-Haushaltes sowohl bei der Mutter als beim Feten konstant.

Die vorliegenden Untersuchungen zeigen, daß Feten von stoffwechselgesunden Müttern auf eine Glukosebelastung nur mit einer geringfügigen Insulinsekretion reagieren. Eine chronische Hyperglykämie, wie sie bei Feten von Müttern mit schlecht eingestelltem Diabetes mellitus oder latentem Diabetes mellitus vorliegt, könnte über eine Stimulation des fetalen Pankreas zur vorzeitigen Reifung der Inselzellen führen. Daraus resultiert bei Glukosebelastung eine übermäßig gesteigerte Sekretion von Insulin.

Schlüsselwörter: Fet, Glukon, Glukoseinfusionen, Insulin, Mutter, Säure-Basen-Haushalt.

\section{Résumé}

Glucose du sang maternel et foetal, controlé de l'insuline et de l'équilibre acidobasique après infusion de glucose a la mère

Le présent article se propose d'étudier la concentration de glucose et la sécrétion d'insuline maternelles et foetales après infusion de glucose à la mère.

Les examens ont été effectués sur 11 primipares dans la 38-40ème semaine de grossesse pendant la période de dilatation du col. Après une injection de bol de $330 \mathrm{mg}$ de glucose/ $\mathrm{kg}$ de poids du corps, on a infusé à la mère $27,5 \mathrm{mg} / \mathrm{kg}$ poids du corps/min. de glucose pendant 60 minutes pour maintenir un taux de glucose constant. Avant et durant l'infusion on a déterminé chez la mère et chez le foetus la concentration de glucose, l'insuline immuno-réactive, le pH et l'excès basique. La concentration de glucose de la mère a atteint en $10 \mathrm{~min} .280,0 \mathrm{mg} \%$
(SD 25,9 ) et au bout des $60 \mathrm{~min}$. d'infusion $326,5 \mathrm{mg} \%$ (SD 46,9). La concentration de glucose du foetus a augmenté de façon continue pour passer des $65,8 \mathrm{mg} \%$ (SD 5,8) du début de l'infusion à $249,2 \mathrm{mg} \%$ (SD 24,0) à la fin des $60 \mathrm{~min}$. d'infusion.

En même temps, que la hausse de la concentration de glucose chez la mère et le foetus, on a observé une augmentation de l'insuline immuno-réactive (IRI). Au début de l'infusion, l'IRI maternelle était de $24,0 \mu \mathrm{E} / \mathrm{ml}$ (SD 8,0$)$ et, après $60 \mathrm{~min}$-d'infusion, de $152,3 \mu \mathrm{E} / \mathrm{ml}$ (SD 51,5 ). La concentration d'insuline foetale était de $17,0 \mu \mathrm{E} / \mathrm{ml}(\mathrm{SD} \mathrm{5,2)}$ au début de l'infusion et augmenta de $86,5 \%$ (SD 80,5) en fin d'une infusion de 60 minutes de glucose à la mère. Par contre, la sécrétion d'insuline du foetus évolue tout différemment lorsque la mère souffre d'un diabetes mellitus latent. L'IRI, de $26,0 \mu \mathrm{E} / \mathrm{ml}$ avant 
l'infusion, monta à $215,6 \mu \mathrm{E} / \mathrm{ml}$ après 60 min. d'infusion continue.

On a observé une corrélation entre la hausse de la concentration d'insuline foetale pro hausse de la concentration de glucose du foetus avec le poids à la naissance après une infusion continue de $60 \mathrm{~min}$.

Pendant l'infusion de glucose à la mère, les paramètres de l'équilibre acidobasique ont été constants aussi bien chez la mère que chez le foetus.
Les analyses présentes montrent que les foetus de mères au métabolisme normal ne réagissent que par une faible sécrétion d'insuline à une charge de glucose. Une hypergly cémie chronique, comme c'est le cas pour les foetus de mères ayant un diabetes mellitus mal réglé ou latent, pourrait conduire par stimulation du pancréas foetal à une maturation précoce des îlots de Langerhans avec, pour conséquence d'une charge de glucose, une sécrétion excessivement accrue d'insuline.

Mots-clés: Equilibre acidobasique, foetus, glucose du sang, infusion de glucose, insuline, mère

Bibliography

[1] BASSETT, J. M., D. MADILL, D. H. NICOL, G. D. THORBURN: Further studies on the regulation of insulin release in foetal and post-natal lambs: The role of glucose as a physiological regulator of insulin release in utero. In: Foetal and Neonatal Physiology, Cambridge University Press (1973)

[2] BASSETT, J. M., D. MADILL: The influence of maternal nutrition on plasma hormone and metabolic concentrations of foetal lambs. J. Endocr. 61 (1974) 465

[3] BATTAGLIA, F.C., G. MESCHIA: Foetal metabolism and substrate utilization. In: Foetal and Neonatal Physiology, Cambridge University Press (1973)

[4] BEARD, R. W., R. C. TURNER, N. W. OAKLEY: Fetal response to glucose loading. Post-Grad. Med. J., London 47 (1971) 68

[5] BERGMEYER, H. U.: Methoden der enzymatischen Analyse. Chemie, Weinheim/Bergstraße 1974

[6] BOSSART, H., S. PAPADOPOULOS: La glycémie maternelle et foetale sub partu. Gynaecologia, Basel 162 (1966) 360

17] CORDERO, L., J. A. GRUNT, G. ANDERSON: Hypertonic glucose infusion during labor. Amer. J. Obstet. Gynec. 15 (1970) 560

[8] ELY, A. P.: The placental transfer of hexoses and polyols in the guinea-pig, as shown by umbilical perfusion of the placenta. J. Physiol., Lond. 184 (1966) 255

[9] FEIGE, A., W. KÜNZEL, M. CORNELY, H. J. MITZKAT: Die Beziehung von Glucosestoffwechsel und Säure-Basen-Status des Feten während der $\mathrm{Ge}-$ burt. In: DUDENHAUSEN, J. W., E. SALING, E. SCHMIDT: Perinatale Medizin Band VI. Thieme Stuttgart

[10] FEIGE, A., W. KÜNZEL, M. CORNELY, H. J. MITZKAT: Die Beziehung zwischen Glukosekonzentration und Säure-Basen-Status im maternen und fetalen Blut während der Geburt. Z. Geburtsh. Perinat. 180 (1976) 106

[11] FEIGE, A., H. J. MITZKAT: Correlations between glucose disappearance rate (K-value) and serum IRI and HPL levels in pregnancy. In: ALMQUIST and WIKSELL International, Perinatal Medicine Stockholm (1976) 112

[12] FRIEDEL, R., A. DWENGER, S. KÄSTNER, I. TRAUTSCHOLD: Teilautomatisierung von Radioimmunoassays mit Hilfe eines' diskontinuierlichen Analysensystems. Z. Klin. Chem. Klin. Bioch. 1 (1974) 45
[13] GARDMARK, S., G. GENNSER, L. JACOBSON, G. ROOTH, J. THORELL: Influence on fetal carbohydrate and fat metabolism and on acid-base balance of glucose administration to the mother during labour. Biol. Neonate 26 (1975) 129

[14] HOLMBERG, N. G., B. KAPLAN, M. J. KARVONEN, J. LIND, M. MALM: Permeability of human placenta to glucose, fructose and xylose. Acta physiol. scand., Stockholm 36 (1956) 291

[15] KASTENDIECK, E., W. MOLL: The transfer of lactic acid across the guinea-pig placenta. In: Perinatal Medicine, distributed by ALMQUIST and WIKSELL International, Stockholm (1976) 50

[16] LIND, T., E. A. GILMORE, M. MCCLARENCE: Cord plasma glucose and insulin concentrations and maternal-fetal relations. Brit. J. Obstet. Gynaecol. 82 (1975) 562

[17] MANN, L. I., J. W. PRICHARD, D. SYMMES: The effect of glucose loading on the fetal response to hypoxia. Amer. J. Obstet. Gynec. 107 (1970) 610

[18] MESCHIA; G., F. C. BATTAGLIA: Acute changes of oxygen pressure and the regulation of uterine blood flow. In: Foetal and Neonatal Physiology, Cambridge University Press (1973)

[19] MILNER, R. D. G., C. N. HALES: Effect of intravenous glucose on concentration of insulin in maternal and umbilical cord plasma. Brit. med. J. 1 (1965) 284

[20] OAKLEY, N. W., R. W. BEARD, R.C. TURNER: Effect of sustained maternal hyperglycaemia on the fetus in normal and diabetic pregnancies. Brit. med. J. 1 (1972) 466

[21] PATERSon, P., D. PAge, P. TAFt, L. Phillips, C. WOOD: Study of fetal and maternal insulin levels during labour. J. Obstet. Gynec. Brit. Cwlth. 75 (1968) 917

[22] REYNOLDS, W. A., R. M. PITKIN: Fetal insulin response: a reexamination. Gynec. Invest. 7 (1976) 48

[23] SABATA, V., H. FRERICHS, H. WOLF, P. STUBBE: Insulin and glucose levels in umbilical cord blood after infusions of glucose and glucose with insulin to women in labour. J. Obstetr. Gynaec. Brit. Comm. 77 (1970) 121

[24] SHELLEY, H. J.: The use of chronically catheterized foetal lambs for the study of foetal metabolism. In: Foetal and Neonatal Physiology, Cambridge University Press (1973) 360 
[25] SHELlEY, H. J., J. M. BASSETT: Control of Carbohydrate Metabolism in the fetus and Newborn. B. Med. Bull. 31 (1975) 37

[26] SIlveR, M., D. H. STEVEN, R. S. COMLINE: Placental exchange and morphology in ruminants and the mare. In: Foetal and Neonatal Physiology, Cambridge University Press (1973) 245

[27] SIMMONS, M. A., G. MESCHIA, E. L. MAKOWSKI, F. C. BATTAGLIA: Fetal metabolic response to maternal starvation. Pediat. Res. 8 (1974) 830

[28] SPELLACY, W. N.: Maternal and fetal metabolic interrelationships. In: SUTHERLAND, H. W., J. M. STOWERS: Carbohydrate Metabolism in Pregnancy and the Newborn. Churchill Livingstone, EdinburghLondon-New York 1975
[29] STEELE, S. M., G. B. JACKSON, A. STARK WOLKOFF: Some aspects of blood lactate levels in mother and fetus. Amer. J. Obstet. Gynec. 105 (1969) 569

[30] WERNER, CH., W. SCHNEIDERHAN: Plazentamorphologie und Plazentafunktion in Abhängigkeit von der diabetischen Stoffwechselführung. Geburtsh. u. Frauenheilk. 32 (1972) 959

[31] WIDDAS, W. F.: Inability of diffusion to account for placental glucose transfer in the sheep and consideration of the kinetics of a possible carrier transfer. J. Physiol. 118 (1952) 23

Received July 28, 1976. Accepted November 24, 1976.

Dr. med. A. Feige

Prof. Dr. med. W. Künzel

Universitäts-Frauenklinik Würzburg Josef-Schneider-Straße 4

D-8700 Würzburg

Prof. Dr. med. H.-J. Mitzkat

Arbeitsgruppe Diabetologie im

Dept. Innere Medizin,

Med. Hochschule Hannover

Pasteurallee 5

D-3000 Hannover 